\title{
A Novel Directly Compressible Co-Processed Excipient for Sustained Release Formulation
}

\author{
Avinash Gangurde ${ }^{1}$, Rahul Kashinath Patole ${ }^{1}$, Ajay Kumar Sav ${ }^{1 *}$, Purnima Dharnraj Amin ${ }^{1}$ \\ ${ }^{1}$ Department of Pharmaceutical Sciences and Technology, Institute of Chemical Technology, Matunga, Mumbai-400019, Maharashtra, India.
}

\section{ARTICLE INFO \\ Article history: \\ Received on: 24/08/2013 \\ Revised on: 10/09/2013 \\ Accepted on: 22/09/2013 \\ Available online: 30/09/2013}

Key words:

Polyethylene oxide,

hydroxyl propyl methyl

cellulose, Co-processing,

Sustained Release,

Dissolution.

\begin{abstract}
A novel directly compressible (DC) co-processed excipient with improved functionality and masking the undesirable properties of individual excipients was developed without any chemical modification by using simple laboratory technique. For the development of co-processed excipient, release retarding polymers such as Polyethylene oxide (Polyox ${ }^{\circledR}$ WSR 301) and hydroxyl propyl methyl cellulose (Methocel ${ }^{\circledR}$ K4M) were used. Co-processed excipient was prepared in polymers weight ratio of 1:9 to 9:1 by roller compaction technique. Co-processed excipient prepared from polymers ratio of 7:3 and 8:2 showed good physico-chemical properties. The developed DC grade co-processed excipient was characterized for DSC, FTIR, SEM, XRD which confirms the absence of any chemical changes during co-processing. Highly water soluble Metoprolol succinate and poorly water soluble anhydrous Theophylline was used as model drugs for Invitro release study. Formulations prepared using co-processed excipient showed sustain drug release in which initial burst release was controlled by polyethylene oxide and HPMC controls the extended drug release. Developed formulations were kept for stability study for three month as per ICH guidelines and found to be stable. Study indicates that use co-processed excipient has added advantage over polymer with single property and can be used in sustain release formulation irrespective of drug type.
\end{abstract}

\section{INTRODUCTION}

In recent time, excipients are the largest components of any pharmaceutical formulation (Russell, 2004). The International Pharmaceutical Excipients Council defines excipients are the substances which present in a finished pharmaceutical dosage form other than the active drug substance. Excipients have been appropriately evaluated for safety and are included in a drug delivery system to aid the processing of the drug delivery system during its manufacture, enhance stability, bioavailability, patient acceptability or enhance any other attributes of the overall safety and effectiveness of the drug delivery system during storage or use (Ogaji et al., 2012). Optimal use and excipients with multifunctional property can provide pharmaceutical manufacturers with cost-savings in drug development and help in drug formulations innovation.

* Corresponding Author

Ajay Kumar Sav, Department of Pharmaceutical Sciences and

Technology, Institute of Chemical Technology, N. P. Marg, Matunga,

Mumbai 400019, India. Tel.: +91-22-3361 1111/2222;

Fax: +91-22-3361 1020, Phone: +91-9619790418
Tablets, are the most commonly used solid pharmaceutical dosage form which was prepared by wet granulation, dry granulation, or direct compression method. Now a days, most of the pharmaceutical manufacturing industries opting for direct compression tableting as it requires fewer processing steps, simplified validation, elimination of heat and moisture, economy, and improved drug stability compared with wet granulation technique (Ayypan et al., 2010). The term 'direct compression' (DC) is the process by which tablets are prepared directly from the powder blends of active ingredients and suitable excipients. For direct compression its prerequisite that excipient used for formulation should have good flow and compression property (Villanova et al., 2011).

There are only few excipients which exhibits all the ideal characteristics required for direct compression. Excipients with improved functionality can be obtained by developing new chemical excipients, new grades of existing materials and new combination of existing materials. The New combinations of existing excipients is an interesting option for improving 
excipients functionality as most of the formulations contain multiple excipients. A much broader platform for the manipulation of excipient functionality is provided by coprocessing or particle engineering of two or more excipients. Co-processing is based on the novel concept of two or more excipients interacting at the sub particle level, the objective of which is to provide a synergy of functionality improvement as well as masking the undesirable properties of individual (Gohel and Jogani, 2003; Gonnissen et al., 2007). Coprocessing leads to the formation of excipients that granulates with superior properties compared with physical mixtures of components or individual components (Mallipeddi et al., 2010; Goehl, 2005 ).

Polyox ${ }^{\circledR}$ WSR 301 is water soluble resin non-ionic, thermoplastic in nature and linear polymer of ethylene oxide. It is fastest hydrating water soluble polymer which quickly forms hydrogel that inhibit and regulate release of active ingredients ( Patel and Patel, 2009). The major pharmaceutical applications of Polyox ${ }^{\circledR}$ WSR 301 have been in the production of dry blends, direct compression tablets. Methocel ${ }^{\circledR} \mathrm{K} 4 \mathrm{M}$ a water -soluble polymer derived from cellulose, the most abundant polymer in nature which is used as the controlled release agent in hydrophilic matrix systems. It has a selflubricating quality and thus it requires less lubrication than other excipients. In addition, it exhibits inherent compatibility because of plastic deformation and limited elastic recovery. One of the few problems associated with cellulose is its very poor flow ability, which can lead to variability of the drug content in the finished dosage form. Hence, it needs to be modified into large particle with improved flow properties.

Thus this work focused on development of directly compressible co-processed excipients comprising of polyethylene oxide and Hydroxyl propyl methyl cellulose by roller compaction method and evaluation as a sustained release matrix forming polymer using water soluble Metoprolol succinate and poorly water soluble anhydrous Theophylline as model drugs.

\section{MATERIALS AND METHODS}

\section{Materials}

Polyethylene oxide (Polyox ${ }^{\circledR}$ WSR 301) and Hydroxyl propyl methyl cellulose (Methocel ${ }^{\circledR} \mathrm{K} 4 \mathrm{M}$ ) were procured from the Dow Chemical Co., USA . Metoprolol succinate was obtained as gift sample from Aurobino Pharma ltd. India and anhydrous Theophylline IP was procured as gift sample from Bajaj Healthcare Ltd, Mumbai, India. Other ingredients and excipients used were of analytical grade.

\section{Preparation of directly compressible co-processed excipients}

In roller compaction method the fine powder force between two counter rotating rolls. As the volume decreases through the region of maximum pressure, the powder material is formed into solid compacts and sheets. Roller compaction basically consists of three steps, i.e., powder feeding, predensification and ribbon formation. During the feeding step, the powder material was fed into two counter-rotating rolls by either gravity or force-feeds screws. Once the powder material was drawn into the nip angle area, it rubs against the roll surface and undergoes the pre-densification process. The predensified powder material was further subjected to pass through the rotating rolls and particles are deformed or fragmented to form ribbons under hydraulic pressure. These ribbons were then sized through desired screens to produce granules to be compressed into tablets.

Polymers were accurately weighed as per specified ratio (1:9 to 9:1) and mixed for $10 \mathrm{~min}$ to form uniform blend. These blends were used for compaction using roller compactor (Clit roller compactor, India). The obtained ribbons were screened through $40 \#$ and $60 \#$ sieve. The obtained fine powder was further recycled to get granules of uniform size. About 9 cycles of roller compaction were performed to obtain the granules of desired size. Material retained on 60 \# sieve was used for further study. Physical mixtures of Polyox ${ }^{\circledR}$ WSR 301 and Methocel ${ }^{\circledR}$ K4M were also prepared in same ratio in a lab scale double cone blender.

\section{Evaluation of co-processed excipients}

The prepared co-processed excipients were characterized for physical properties such as flow, density and compressibility. The bulk density and tapped bulk density were determined by using density apparatus (VEEGO, India). Compressibility was defined by Carr's indices (CI) and Hausner's ratio values. Carr's indices (CI) and the Hausner's ratio were calculated from the obtained density values. Flow property (angle of repose) was determined by fixed funnel method (Bagdiya et al., 2012). Moisture content was determined using moisture content analyzer MB 50C (CITIZEN, India).

\section{Swelling index}

Swelling behavior was evaluated by reported method with some modification (Sav et al., 2013). A weighed quantity of sample was incubated at $37^{\circ} \mathrm{C}$ for $24 \mathrm{~h}$ in purified water. For incubation, samples were placed in $100 \mathrm{ml}$ graduated glass cylinder containing $100 \mathrm{ml}$ of media. The swelling index (SI) was calculated by using following equation:

Swelling Index $=($ Final volume - Initial volume $) /$ Final volume $\times 100$

\section{Hardness and friability}

Hardness and friability are indicative of the mechanical strength of the tablets. Representative sample of the tablets were tested for hardness using a Monsanto hardness tester. Friability evaluations on the tablets were performed using Roche friabilator. A preweighed tablet sample was placed in the friabilator and operated for at $25 \mathrm{rpm}$ for 
4 min (Bourne, 2002). The tablets were dusted and reweighed for determination of friability.

\section{CHARACTERIZATION OF CO-PROCESSED EXCIPIENTS}

\section{Fourier transforms infrared spectroscopy (FTIR)}

FTIR spectra were acquired on a Perkin Elmer spectrum RX FTIR instrument. Spectra over a range of 4000$400 \mathrm{~cm}^{-1}$, with threshold of 1.303 , sensitivity of 50 and resolution of $2 \mathrm{~cm}^{-1}$ range were recorded on $\mathrm{KBr}$ disc $(5 \mathrm{mg}$ of the powder samples per $400 \mathrm{mg}$ of $\mathrm{KBr}$ ). Spectra were recorded for Polyox ${ }^{\circledR}$ WSR 301, Methocel ${ }^{\circledR}$ K4M, and the coprocessed excipient.

\section{Differential scanning calorimetry (DSC)}

DSC studies were carried out using a DSC Perkin Elmer pyris-6 (USA) equipped with a thermal analysis system. Samples of Polyox $^{\circledR}$ WSR 301, Methocel $^{\circledR}$ K4M and coprocessed excipient (approximately $2 \mathrm{mg}$ each) were individually used for DSC analysis. Dry nitrogen was used as the purge gas (purge $20 \mathrm{ml} \mathrm{min}^{-1}$ ). The probes were heated from 25 to $265{ }^{\circ} \mathrm{C}$ at a rate of $5^{\circ} \mathrm{C} \mathrm{min}{ }^{-1}$. The relevant thermodynamic parameters were evaluated with analysis software (Philip et al., 2010).

\section{$X$ ray Diffractometry(XRD)}

X-ray Diffractogram was recorded on Rigaku Miniflex instrument for polymers using Ni filtered, $\mathrm{CuK}_{\text {alpha }}$ radiation, a voltage of $40 \mathrm{Kv}$, and a $25 \mathrm{~mA}$ current. All the percent crystallinity was calculated for 2 theta values $10^{\circ}-60^{\circ}$. Crystal size was determined using the Debye-scherrer equation.

\section{Scanning Electron Microscopy (SEM)}

The scanning electron micrographs were obtained for Polyox ${ }^{\circledR}$ WSR 301, Methocel ${ }^{\circledR}$ K4M and developed co-processed excipients. Samples were prepared by gold-plating, while imaging was carried out on a scanning electron microscope (JSM-6380LA, Jeol, Japan).

\section{Preparation of sustained release matrix tablet formulation}

Highly water soluble drug like Metoprolol succinate and poorly water soluble Theophylline anhydrous were selected for evaluating the release retarding property of coprocessed excipients. Matrix tablet formulations were prepared using the developed co-processed excipients. The formulation compositions for both the drug are shown in table 1 and 2. Polymer loading was varied from $10-60 \%$ and drug dose kept constant to study the effect of polymer concentration on drug release. Matrix tablets were prepared on ten station rotary tablet press using standard tooling. Prepared tablets were subjected to the various quality control parameters such as hardness, friability, weight variation, diameter and drug content as per reported method.
Table. 1: Formulation compositions for Metoprolol succinate batches

\begin{tabular}{lcccc}
\hline \multicolumn{1}{c}{ Ingredients } & MT-5 $_{(\mathbf{5 0} \%)}$ & MT-6 $_{(\mathbf{6 0} \%)}$ & MT-7 $_{(\mathbf{5 0} \%)}$ & MT-8 $_{(\mathbf{6 0} \%)}$ \\
\hline Metoprolol succinate & 100 & 100 & 100 & 100 \\
Co-processed excipient & 175 & 210 & 175 & 210 \\
(7:3/8:2 ratio) & & & & \\
Avicel PH 102 & 70 & 35 & 70 & 35 \\
Magnesium stearate & 3.5 & 3.5 & 3.5 & 3.5 \\
Talc & 1.5 & 1.5 & 1.5 & 1.5 \\
Total (mg) & 350 & 350 & 350 & 350 \\
\hline
\end{tabular}

Table. 2: Formulation compositions for Theophylline anhydrous batches.

\begin{tabular}{|c|c|c|c|c|}
\hline Ingredients & T-1 $(10 \%)$ & T-2 $(20 \%)$ & T-3 $(10 \%)$ & T-4 $(20 \%)$ \\
\hline Theophylline Anhydrous & 200 & 200 & 200 & 200 \\
\hline $\begin{array}{l}\text { Co-processed excipient } \\
\text { (7:3/8:2 Ratio) }\end{array}$ & 21.62 & 46.25 & 21.62 & 46.25 \\
\hline Magnesium stearate & 2. 25 & 2.5 & 2.25 & 2.5 \\
\hline Talc & 1.12 & 1.25 & 1.12 & 1.25 \\
\hline Total (mg) & 225 & 250 & 225 & 250 \\
\hline
\end{tabular}

\section{In vitro release}

In-vitro drug release of Metoprolol succinate was performed using a USP dissolution test apparatus II (model TDT-08L, Electrolab, India) fitted with paddles rotating at $100 \mathrm{rpm}, 500 \mathrm{ml} \mathrm{pH} 6.8$ phosphate buffer as dissolution medium. An aliquot of $10 \mathrm{ml}$ was withdrawn at 1, 4, 12 and $24 \mathrm{~h}$ interval and replaced with same amount of fresh media. Invitro drug release of Theophylline anhydrous was performed using a USP dissolution test apparatus II fitted with paddles rotating at $100 \mathrm{rpm}$ using $1000 \mathrm{ml} \mathrm{pH} 6.6$ Phosphate buffer as dissolution medium. An aliquot of $10 \mathrm{ml}$ was withdrawn at 1 , 2, 4, 5 and $8 \mathrm{~h}$ interval and replaced with same amount of fresh media. Temperature at $37 \pm 0.5^{\circ} \mathrm{C}$ was maintained during both the dissolution study. All the withdrawn samples were filtered through $0.45 \mu \mathrm{m}$ filter paper and analysed for drug release using UV-Visible spectrophotometer 1600 (Shimadzu) at $223 \mathrm{~nm}$ and $273 \mathrm{~nm}$ respectively.

\section{Kinetic analysis of release data}

The obtained dissolution data was fitted to Zero order, First order, Higuchi, Hixon -Crowell and KorsmeyerPeppas equations to understand the rate and mechanism of drug release from the prepared formulations. The correlation coefficients $\left(r^{2}\right)$ values were calculated and used to find the fitness of the data (Bagdiya et al., 2013).

\section{Stability study}

The optimized formulations were kept for stability study at $40{ }^{\circ} \mathrm{C} \pm 2{ }^{\circ} \mathrm{C} / 75 \pm 5 \% \mathrm{RH}$ for three months. Sample was withdrawn at predetermined time intervals of $0,30,60$ and 90 days and evaluated for invitro drug release.

\section{RESULTS AND DISCUSSION}

\section{Evaluation of co-processed excipients}

Physical properties of material to be used as an excipient in direct compression formulations are of critical importance. Therefore, physical processes such as mixing, bulk particle movement and compaction are mainly depend 
on the powder particle characteristics. The efficiency of flow ability of a direct compressible excipient in automated technology employing rotary compression system is essential for production of tablets with uniform weight (Bolhuis et al., 1996).

The flow and compressibility characteristics of Polyox ${ }^{\circledR}$ WSR 301, Methocel ${ }^{\circledR}$ K4M and the various samples of their co-processed excipient were indirectly assessed by determining their angle of repose and Carr's compressibility indices. An angle of repose value less than $25^{\circ}$ is considered to have very good flow whereas $50^{\circ}$ is poor (Well, 2003). A Carr's indices values below $15 \%$ represent good compressibility while values above $25 \%$ indicate poor compressibility.

Results depicted in Fig. 1 suggested that all the coprocessed excipients have improved flow ability and compressibility than their physical mixture and individual polymer. It was also observed that Methocel ${ }^{\circledR} \mathrm{K} 4 \mathrm{M}$ has poor flow property as compared to Polyox ${ }^{\circledR}$ WSR 301 and coprocessed excipient. Co-processed excipient prepared in Polyox ${ }^{\circledR}$ WSR 301 and Methocel $^{\circledR}$ K4M ratio of 7:3 and 8:2 showed good flow properties and compressibility as compared to other ratios of selected combinations and physical mixtures. The optimized ratio $7: 3$ and $8: 2$ also showed good tableting properties as shown in Fig. 2. The moisture content of the coprocessed excipient was found to be less than $1 \%$. Swelling study showed that all the co-processed excipient has similar swelling property $(40-50 \%)$ as indicated in Fig.2.

\section{Fourier transform infrared spectroscopy (FT-IR) and X- ray Diffractometry}

FTIR spectroscopy is a quick and simple technique for identifying any chemical changes or interaction. FTIR spectra of Polyox ${ }^{\circledR}$ WSR 301 showed characteristic peak at $2890 \mathrm{~cm}^{-1}$ due to $\mathrm{H}-\mathrm{C}-\mathrm{H}$ asymmetric stretching and symmetric stretching at $1400 \mathrm{~cm}^{-1}$ of alkane as functional group. A stretching vibration at $1100 \mathrm{~cm}^{-1}$ was observed due to $\mathrm{C}-\mathrm{O}$ of diethyl ether as functional group. FTIR spectra of Methocel ${ }^{\circledR}$ $\mathrm{K} 4 \mathrm{M}$ exhibits $-\mathrm{OH}$ vibrational stretching at $3458 \mathrm{~cm}^{-1}$, the symmetric stretching of methyl and Hydroxypropyl group was found at $2922 \mathrm{~cm}^{-1}$.

The band present at $1650-1600 \mathrm{~cm}^{-1}$, indicating stretching vibration of $\mathrm{C}-\mathrm{O}$ for six membered cyclic ring. The band present at $1400-1350 \mathrm{~cm}^{-1}$ suggests C-O-C of cyclic anhydride. FTIR spectra of co-processed excipients showed retention of all the major peaks of individual polymer which indicate absence of chemical interaction between polymers during processing Fig. 3.

\section{Differential scanning calorimetry (DSC)}

DSC is a useful tool for characterizing a particular polymer based on its exothermic and endothermic thermal transitions. DSC thermo grams of Polyox ${ }^{\circledR}$ WSR $301^{\circledR}$, Methocel $^{\circledR}$ K4M and Polyox $^{\circledR}$ WSR 301-Methocel ${ }^{\circledR} \mathrm{K}^{\circledR} \mathrm{M}^{\circledR}$ co- processed excipients are shown in Fig.4. Absences of endotherm in case of Methoce ${ }^{\circledR} \mathrm{K} 4 \mathrm{M}$ indicate its amorphous nature whereas Polyox ${ }^{\circledR}$ WSR 301 showed a broad endothermic peak at $74-75^{\circ} \mathrm{C}$ which was due to melting effect. The DSC thermogram of co-processed excipient exhibits sharp endothermic peak at $74-75^{\circ} \mathrm{C}$ which was corresponding to the melting endotherm of Polyox ${ }^{\circledR}$ WSR 301. Sharpness in endothermic peak was observed due to hydrogen bonding between Methocel $^{\circledR}$ K4M and Polyox ${ }^{\circledR}$ WSR 301 which might be taken place during compaction process.

DSC thermogram of co-processed excipients shows no additional endotherm peaks which suggest that developed co-processed excipients are devoid of any chemical changes.

\section{XRD}

X-ray powder Diffractogram of Polyox ${ }^{\circledR}$ WSR 301 confirms its crystalline nature whereas Methocel $^{\circledR}$ K4M has less crystalline property as indicated by percent crystallinity in table 3 and Fig. 5. X ray study of co-processed excipient revealed retention of crystalline property of Polyox ${ }^{\circledR}$ WSR 301 in final product as it was present in higher ratio. There were no significant change in percent crystallinity and crystal size was observed after co-processing of polymers. Therefore, developed co-processed excipients is comply the criteria for being an inert chemical excipient.

Table. 3: Percent crystalinity and crystal size of polymers.

\begin{tabular}{|c|c|c|c|c|}
\hline \multicolumn{3}{|c|}{ Batch } & $\%$ Crystalinity & Crystal size \\
\hline Polyox ${ }^{\circledR}$ WSR 30 & & & 25.07 & 13.5912 \\
\hline Methocel $^{\circledR}$ K4M & & & 3.44 & 3.348 \\
\hline $\begin{array}{l}\text { Polyox }^{\circledR} \text { WSR } \\
\text { K4M (7:3 ratio) }\end{array}$ & 301 & :Methocel ${ }^{\circledR}$ & 19.48 & 13.6019 \\
\hline $\begin{array}{l}\text { Polyox }^{\circledR} \text { WSR } \\
\text { K4M (8:2 ratio) }\end{array}$ & 301 & :Methocel $^{\circledR}$ & 23.00 & 14.6067 \\
\hline
\end{tabular}

\section{SEM}

The morphology as characterized by the particle shape and size can be used as an important feature for the identification and distinction of different polymers. Polyox ${ }^{\circledR}$ WSR 301 is characterized by granular, round to oval shape particles while Methocel $^{\circledR} \mathrm{K} 4 \mathrm{M}$ occurs as long thin strands with irregular and rough porous surfaces. The developed coprocessed excipient from mixture of the Polyox ${ }^{\circledR}$ WSR 301 and Methocel $^{\circledR} \mathrm{K} 4 \mathrm{M}$ has a peculiar morphology different from those of either the Polyox $^{\circledR}$ WSR 301 or Methocel $^{\circledR}$ K4M particles.

While comparing the morphology obtained for coprocessed excipient with reference to individual polymer it showed bigger particle agglomerate indicating formation of complete new type of polymer. The particle size of the Polyox ${ }^{\circledR}$ WSR 301 was found to be 270-290 $\mu \mathrm{m}$ and coprocessed excipients has particle size $400-420 \mu \mathrm{m}$ range. Scanning electron micrographs of Polyox ${ }^{\circledR}$ WSR 301 and Methocel $^{\circledR} \mathrm{K} 4 \mathrm{M}$ and the developed excipient are shown in Fig.6. 

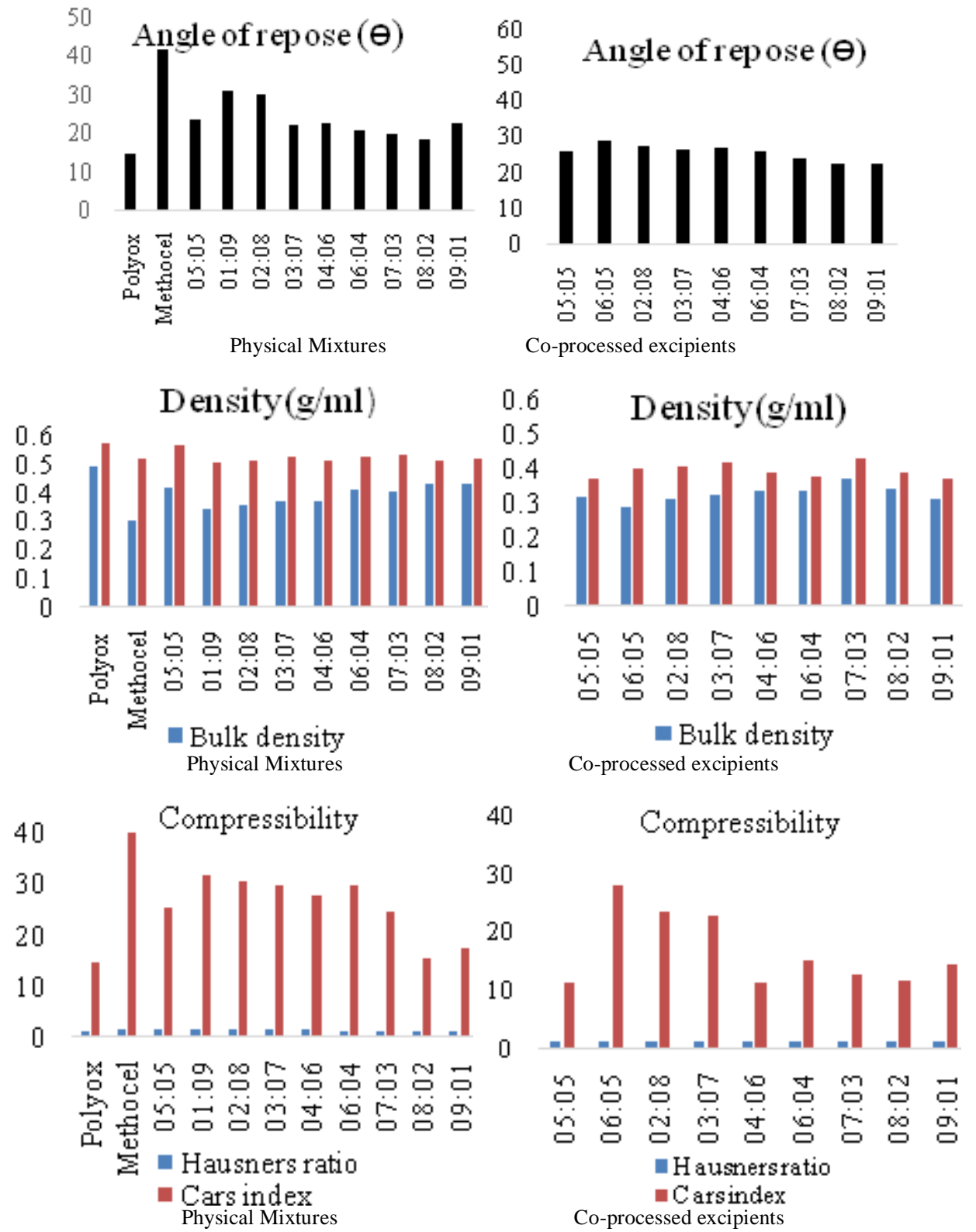

Fig. 1: Physical characteristics of physical mixture and co-processed excipients.

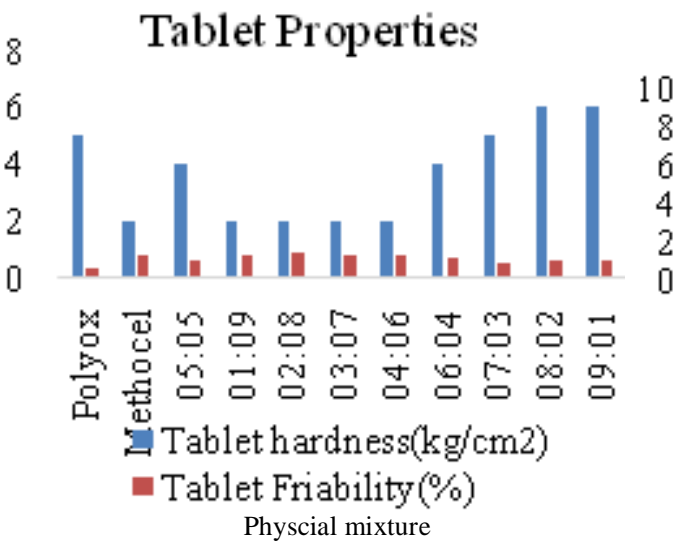

Fig. 2:
Tablet Properties

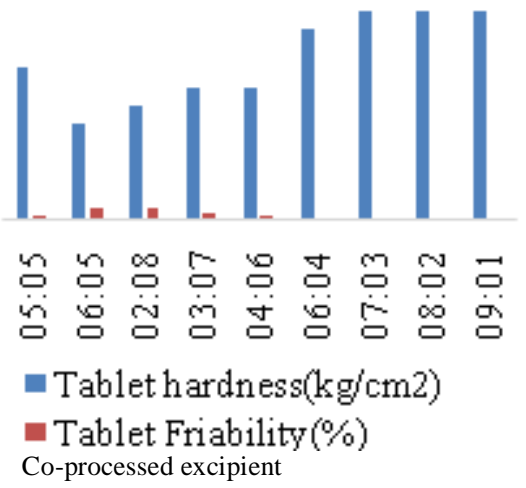




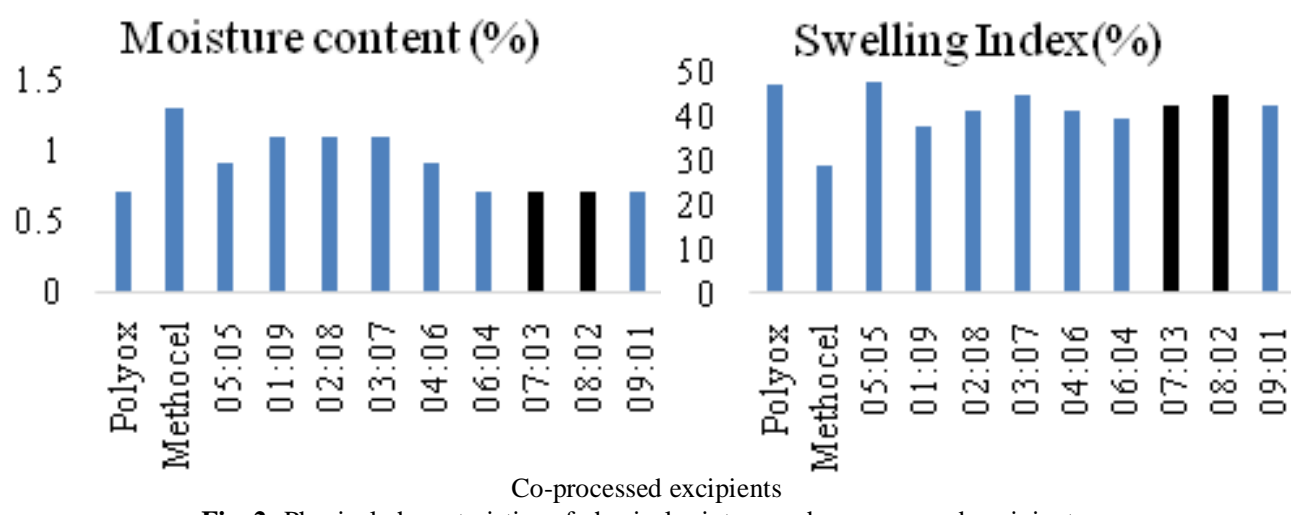

Fig. 2: Physical characteristics of physical mixture and co-processed excipients.

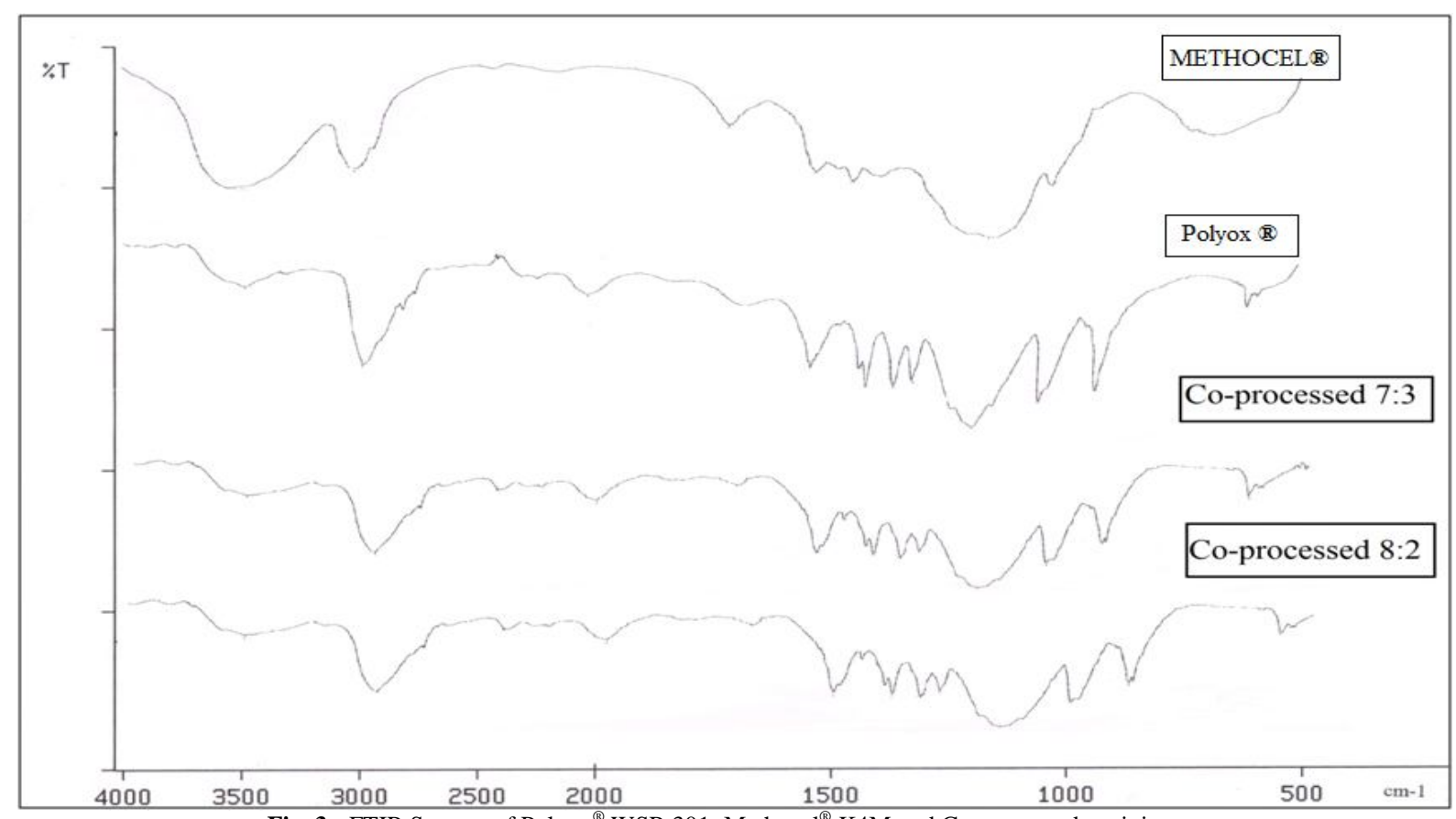

Fig. 3: FTIR Spectra of Polyox ${ }^{\circledR}$ WSR 301, Methocel $^{\circledR}$ K4M and Co-processed excipients.

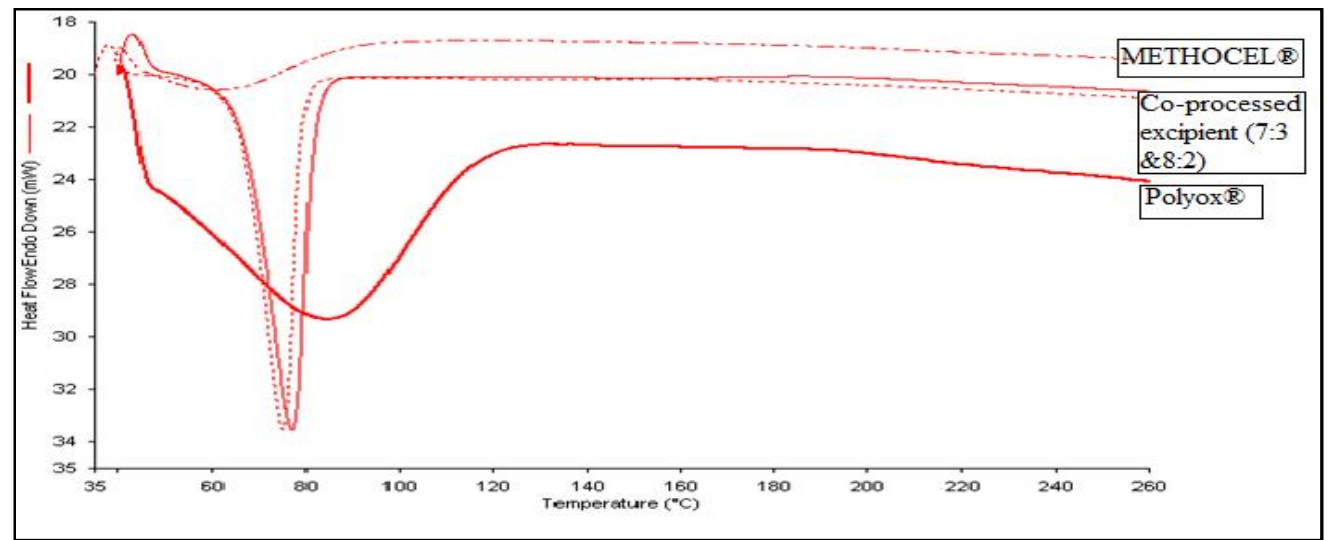

Fig. 4: DSC thermogram of Polyox ${ }^{\circledR}$ WSR 301, Methocel $^{\circledR}$ K4M and Co-processed excipients 

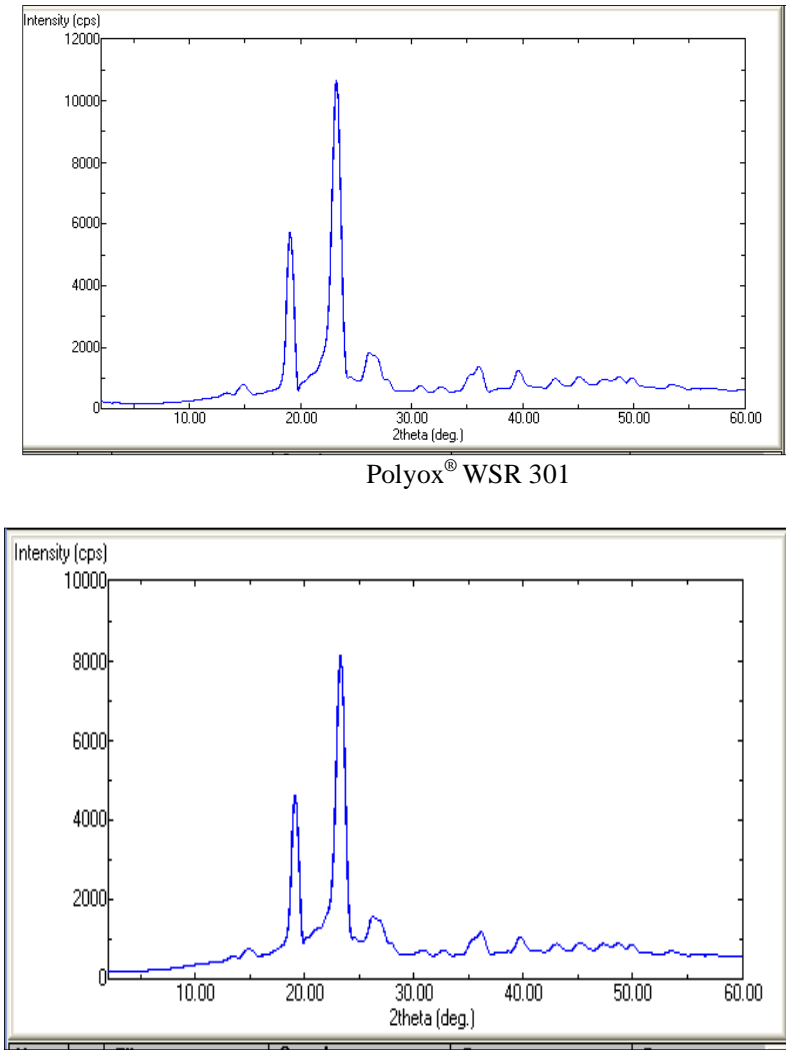

Polyox ${ }^{\circledR}$ WSR 301

Polyox ${ }^{\circledR}$ WSR 301-Methocel ${ }^{\circledR}$ K4M $(7: 3)$

Fig. 5: X-ray Diffractogram of Polyox ${ }^{\circledR}$ WSR 301, Methocel $^{\circledR}$ K4M and Co-processed excipients.

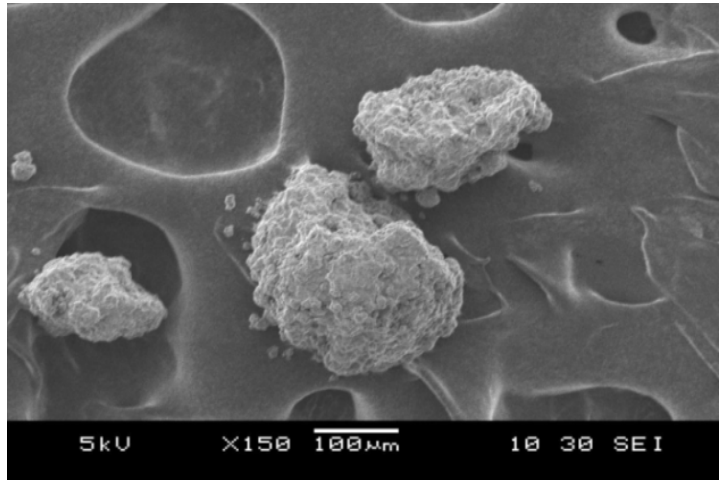

Polyox $^{\circledast}$ WSR 301

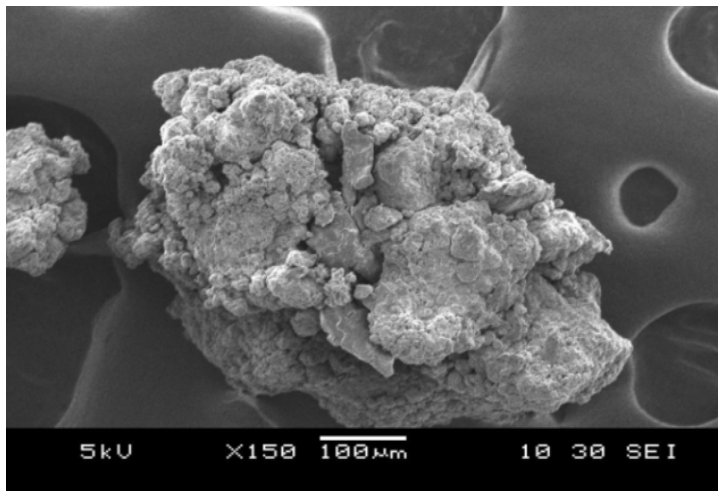

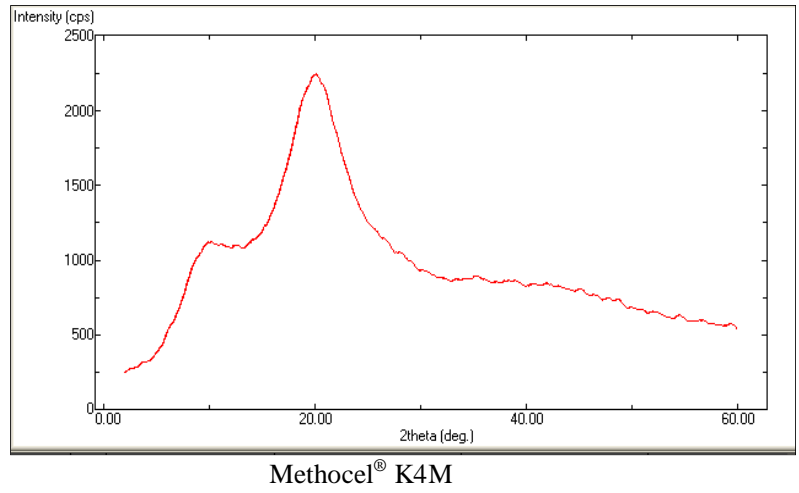

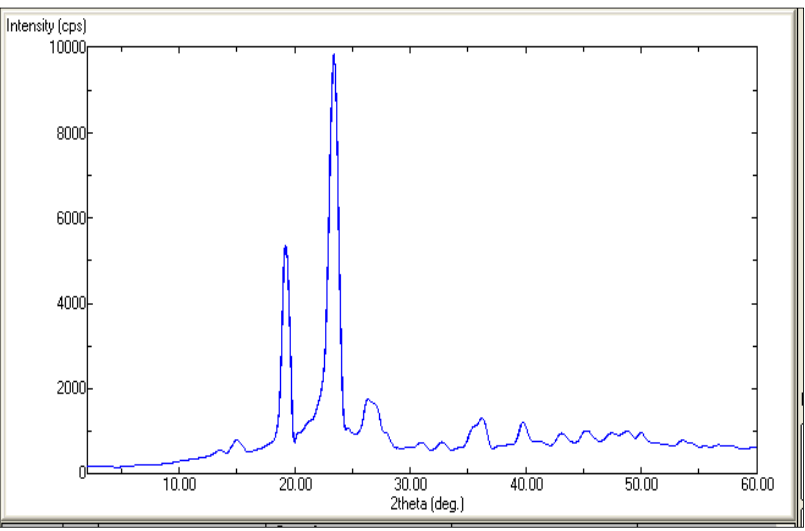

Polyox WSR $301^{\circledR}$-Methocel ${ }^{\circledR}$ K4M $(8: 2)$

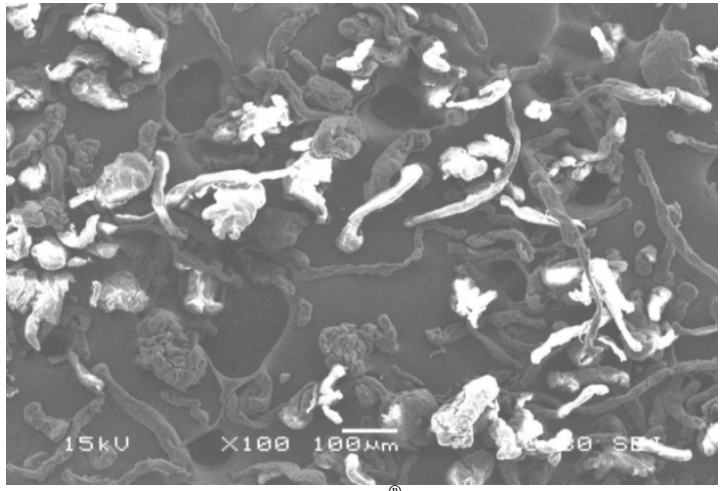

Methocel ${ }^{\circledR} \mathrm{K} 4 \mathrm{M}$

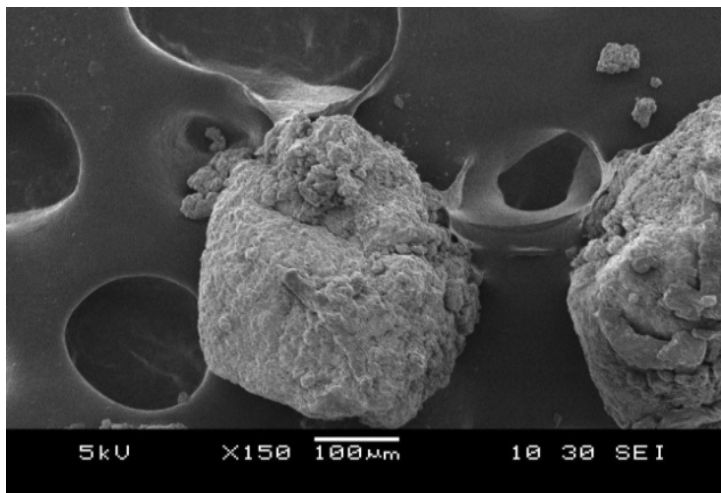

Polyox ${ }^{\circledR}$ WSR 301-Methocel ${ }^{\circledR}$ K4M (8:3)

Fig. 6: Scanning electron micrograph of Polyox ${ }^{\circledR}$ WSR 301, Methocel ${ }^{\circledR}$ K4M and Co-processed excipients. 


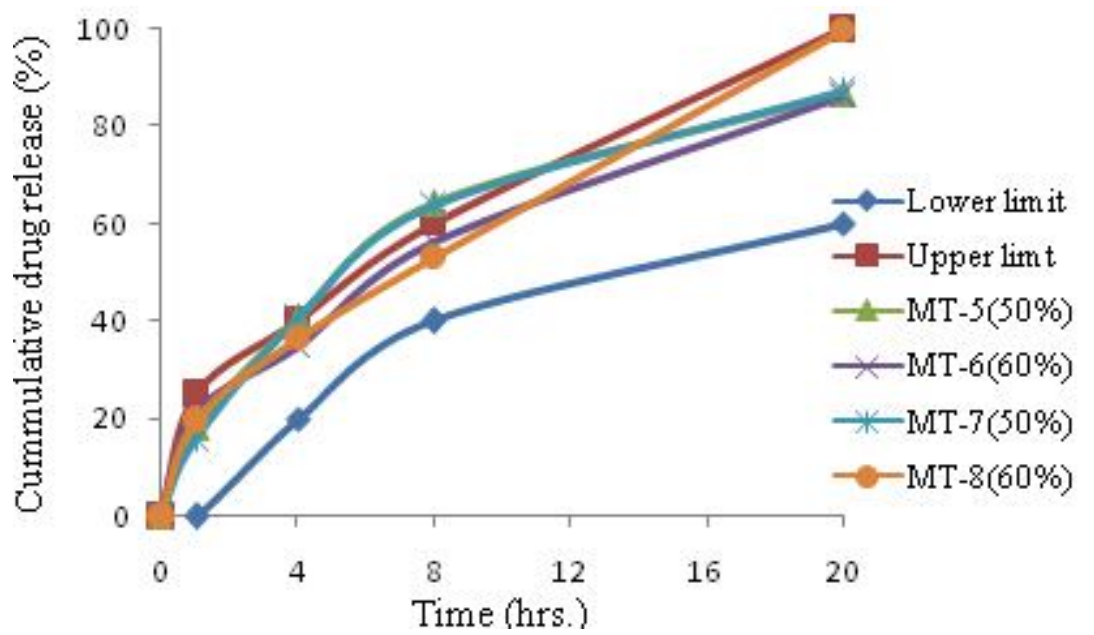

Fig. 7: Dissolution profiles of Metoprolol succinate formulation with 50\% and $60 \%$ concentration of co-processed excipients.

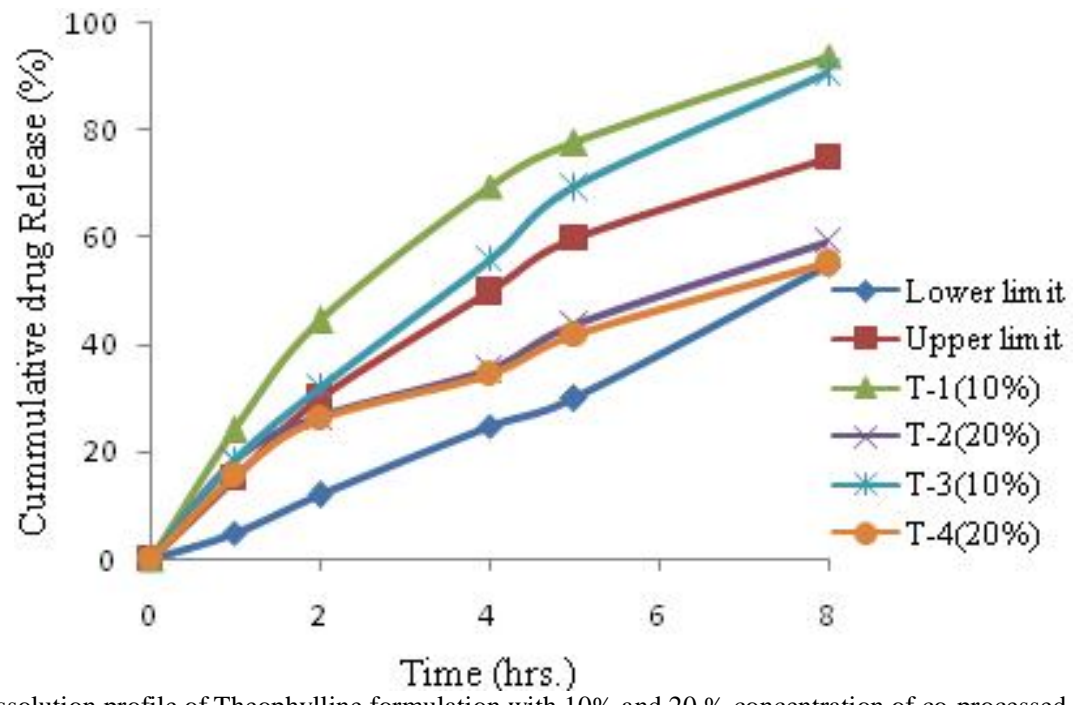

Fig. 8: Dissolution profile of Theophylline formulation with $10 \%$ and $20 \%$ concentration of co-processed excipients.

Table. 4: In vitro drug release Kinetic parameters

\begin{tabular}{|c|c|c|c|c|c|c|c|c|c|c|}
\hline \multirow[t]{2}{*}{ Formulation } & \multicolumn{2}{|c|}{ Zero order } & \multicolumn{2}{|c|}{ First order } & \multicolumn{2}{|c|}{ Higuchi } & \multicolumn{2}{|c|}{ Hixon-crowell } & \multicolumn{2}{|c|}{ Korsemeyer-peppas } \\
\hline & $\mathbf{r}^{2}$ & $\mathbf{k}$ & $\mathbf{r}^{2}$ & $\mathbf{K}$ & $\mathbf{r}^{2}$ & $\mathbf{k}$ & $\mathbf{r}^{2}$ & $\mathbf{k}$ & $\mathbf{r}^{2}$ & $\mathbf{K}$ \\
\hline MT-5 & 0.926 & 15.722 & 0.993 & 1.956 & 0.993 & 20.01 & 0.978 & 8.817 & 0.998 & 8.340 \\
\hline MT-6 & 0.954 & 14.152 & 0.998 & 1.972 & 0.997 & 19.18 & 0.991 & 9.266 & 0.998 & 10.45 \\
\hline MT-7 & 0.929 & 14.959 & 0.995 & 1.962 & 0.992 & 20.33 & 0.980 & 8.673 & 0.998 & 8.315 \\
\hline MT-8 & 0.980 & 11.629 & 0.962 & 2.193 & 0.992 & 21.90 & 0.986 & 5.063 & 0.999 & 9.599 \\
\hline $\mathrm{T}-1$ & 0.966 & 11.840 & 0.991 & 1.951 & 0.980 & 21.93 & 0.969 & 6.533 & 0.995 & 21.22 \\
\hline T-2 & 0.922 & 12.472 & 0.965 & 1.946 & 0.990 & 13.23 & 0.952 & 16.56 & 0.982 & 6.68 \\
\hline $\mathrm{T}-3$ & 0.933 & 13.892 & 0.993 & 1.982 & 0.981 & 21.30 & 0.980 & 7.634 & 0.996 & 4.69 \\
\hline $\mathrm{T}-4$ & 0.915 & 11.712 & 0.955 & 1.948 & 0.991 & 12.49 & 0.942 & 17.88 & 0.976 & 19.39 \\
\hline
\end{tabular}

\section{Extended release matrix tablet formulations}

All formulations batches were evaluated for physical properties such as tablet hardness, weight variations, thickness, diameter and drug content by reported method and found to be in pharmacopoeial acceptable range. The matrix tablet formulations were prepared using directly compressible coprocessed excipient with composition of 7:3 and 8:2 ratio of Polyox $^{\circledR}$ WSR 301 and Methocel ${ }^{\circledR}$ K4M for both drug. Polymer concentration was varied from $10 \%$ to $60 \% \mathrm{w} / \mathrm{w}$ of tablet weight. Matrix tablet prepared from Polyox ${ }^{\circledR}$ WSR 301 alone showed complete drug release in shorter period of time at all polymer level whereas formulation with Methocel $^{\circledR}$ K4M showed highly retarded drug release but not as per USP specification. Metoprolol succinate formulation prepared with $60 \%$ co-processed excipient was able to sustain the drug release as per USP specification Fig 7. High water solubility nature of Metoprolol succinate caused rapidly diffusion through hydrophilic gel barrier system therefore it required high amount of matrix former. This requirement of matrix former was less in case of poorly water soluble drug such as Theophylline anhydrous, it showed desired release profile with only $20 \%$ polymer level Fig. 8 . Mechanism 
involved that hydrophilic matrix systems prepared using coprocessed excipient get wet and hydrate rapidly to forms a gelatinous layer, which protect the interior of the tablet from dissolving and disintegrating which delay the drug release. This study suggest that desired drug release profile can be achieve by carefully selection of type of polymer, concentration of polymer and nature of a drug which is in agreement with earlier reported work (Ganesh et al., 2008). Optimized formulation were found to be followed similar drug release profile after the period of stability study.

\section{Release kinetic analysis}

In vitro drug release profile from all these formulations could be best expressed by Korsmeyer-Peppas equation as all the formulation showed highest correlation coefficient value $\left(\mathrm{r}^{2}\right)$ table 4 . Thus it was concluded that the optimized formulation followed mixed mechanism of diffusion and erosion so called anomalous diffusion mechanism for drug release.

\section{CONCLUSION}

Directly compressible co-processed excipients with improved functional property was developed using Polyox WSR $301{ }^{\circledR}$ and Methocel $^{\circledR}$ K4M without any chemical changes by roller compaction method. Developed co-processed excipient showed good drug release retarding property and could be alternate way to overcome the problems associated with single polymer alone.

\section{ACKNOWLEGEMENT}

Authors are thankful to UGC, India for providing fellowship during research work and Ajanta Pharmaceutical, Mumbai, India for availing the roller compactor facility.

\section{REFERENCES}

Ayyapan J, Umapathi P, Darlin quine. Development and evaluation of a directly compressible Co-processed sustained release agent for tablets. Int J Pharmacy Pharm Sci, 2010; 2: 201-205

Bagdiya O, Sav A, Gejage S, Amin P. Formulation development of Venlafaxine Hydrochloride extended release tablet and invitro characterizations. Int J PharmTech Res, 2012; 4:1777-1784.

Bagdiya $\mathrm{O}$, Sav A, Gejage S, Amin P. Formulation development of venlafaxine hydrochloride extended release pellets by extrusion spheronization method. Int J Pharmacy, 2013; 3: 152-159.
Bolhuis GK, Chowhan ZT, Alderborn G, Nystron C. 1996. Materials for direct Compaction. In: Alderborn, G., Nystron, C. (Eds.), Pharmaceutical Powder Compaction Technology. New York:Marcel Dekker 1: 419-96.

Bourne DWA. 2002. Pharmacokinetics. In: Banker GS, Rhodes CT, Modern Pharmaceutics, $4^{\text {th }}$ ed., New York: Marcel Dekker 67- 92

Ganesh S, Radhakrishnan M, Ravi M, Prasannakumar B, Kalyani J. Invitro evaluation of the effect of combination of hydrophilic and hydrophobic polymers on controlled release zidovudine matrix tablets. Indian J Pharm Sci, 2008; 70:461-465

Gohel MC, Jogani PD. Exploration of melt granulation technique for the development of co-processed directly compressible adjuvant containing lactose and microcrystalline cellulose. Pharm Dev Technol, 2003; 8: 175-185

Gohel MC. Using Methocel cellulose ethers for controlled release of drugs in hydrophilic matrix systems, A review of co-processed directly compressible excipients. J Pharm Sci, 2005; 8: 76-93

Gonnissen Y, Remon JP, Vervaet C. Development of directly compressible powders via co- spray drying Eur J Pharm BioPharm, 2007; 67: $220-226$

Mallipeddi R, Saripella KK, Neau SH. Use of coarse ethyl cellulose and PEO in beads produced by extrusion-spheronization. Int $\mathrm{J}$ Pharm, 2010; 385:53-65

Ogaji IJ, Nep EI, Audu-Peter JD. Advances in natural polymers as pharmaceutical excipients. Pharm Anal Acta, 2012; 3:146

Patel SS, Patel NM. Development of directly compressible coprocessed excipients for dispersible tablets using $3^{2}$ full factorial design. Int J Pharmacy Pharm Sci, 2009; 1: 125-148

Philip F, Bonaventurea BAM, Tiwaladeb A, Okpakoc LC, Attama AA. Novel multifunctional pharmaceutical excipients derived from microcrystalline cellulose-starch micro particulate composites prepared by compatibilized reactive polymer blending. Int J Pharm, 2010; 388:159-167

Russell R. Synthetic excipient challenge all-natural organics offer advantages/challenges to developer and formulators. Pharm Tech, 2004; $27: 38-50$

Sav AK, Fule RA, Ali MT, Purnima Amin. Synthesis and evaluation of octenyl succinate derivative of Fenugreek gum as extended release polymer. J Pharm Investigation, 2013; 43(5): 417-429.

Villanova JCO, Ayres E, Oréfice RL. Design of prolonged release tablets using new solid acrylic excipients for direct compression. Eur J Pharm BioPharm, 2011; 79: 664-673

Well J. 2003. Pharmaceutical preformulation: the physicochemical properties of drug substances. In: Aulton, M.E. (Ed.), The Science of Dosage Form Design, $2^{\text {nd }}$ ed. Toronto: Churchill Livingstone. 113-138.

\section{How to cite this article:}

Avinash Gangurde, Rahul Kashinath Patole, Ajay Kumar Sav, Purnima Dharnraj Amin., A Novel Directly Compressible CoProcessed Excipient for Sustained Release Formulation. J App Pharm Sci, 2013; 3 (09): 089-097. 